\title{
FRAMING OF JOURNALISM DISCOURSE TO IMPROVE DISCOURSE COMPETENCE OF SENIOR HIGH SCHOOL STUDENTS
}

\author{
Dadang S. Anshori \\ FPBS, Indonesia University of Education, Indonesia \\ E-mail: dadanganshori@upi.edu
}

\begin{abstract}
APA Citation: Anshori, D. S. (2017). Framing of journalism discourse to improve discourse competence of senior high school students. English Review: Journal of English Education, 6(1), 137-146. DOI: 10.25134/erjee.v6i1.780.
\end{abstract}

\begin{abstract}
This study aims to describe the analysis model of framing on journalism discourse in Indonesian textbooks in Senior High School to be used in language learning. This research used qualitative method with framing theory from Pan and Kosicki as an tool of analysis. The research data is journalism discourse in textbook amounted to 30 pieces of discourse taken from 10 text books of class X, XI, and XII in Senior High School. The results show the following: (1) The discourse of journalism has received acceptance in the world of education, especially in textbooks. The use of journalism discourse in 10 textbooks is very high and very diverse in terms of number, topic, source, and usage. (2) The journalism discourse in the textbook meets the criteria of reporting value, even if not all reporting value is fulfilled. (3) The frame construction of the journalism discourse in Indonesian textbooks is packaged in different angles according to news topics and facts. (4) The analysis model of journalism discourse framing is developed by focusing on the structural analysis of category, syntax, script, thematic, diction/phrase, and rhetoric.
\end{abstract}

Keywords: construction, discourse, framing, journalism

\section{INTRODUCTION}

The development of information technology leads to the emergence of a variety of language use in accordance with the media used. Information technology becomes a new round of world order and the development of human communication. According to Latief and Ibrahim (1996) this communication revolution if sorted can be started from the stage of pre-spoken, spoken, written, print, mass media to telematics. Schramm's note in Latief and Ibrahim (1996) mentions that the development of telecommunications from spoken to written language took at least 50 million years; from writing to printing took as much as 5,000 years; and printing to audiovisual media (photography, telephone, sound recordings, radio, television) took about 500 years.

The use of Indonesian language in the mass media is increasingly widespread, even forming its own genre, namely Indonesian journalism. Variety of Indonesian journalism is used by journalists to convey information in the form of news to the readers. In fact, in Indonesian journalism, there are variations, such as newspaper journalism, magazine journalism, tabloid journalism, television journalism, radio journalism, and internet journalism. These differences are more due to the functions of the mass media in different times, thus demanding the use of different languages too. Sociolinguistically, the language of journalism is a variation or variety of Indonesian language formed because of differences in delivery media of language, namely print and electronic media. Therefore, the language of journalism is understood as a variety of mass communication languages used by print and electronic media.

In the language of journalism we see two important things, the first is picture of the society's progress in the language, especially related to the language creativity. Journalism language is the daily language of society 


\section{Dadang S. Anshori}

Framing of journalism discourse to improve discourse competence of senior high school students

because the information submitted by the newspaper is consumed daily by millions of Indonesian people. Second, the language of journalism reflects the social dynamics that are in it or that accompany it. Through the language of the mass media we know the dynamics of society from the ideological to the pragmatic life of society. Therefore, in studying the language of journalism we should also see the presence of language function in the context of mass media in the midst of society's dynamics. Thus, we will not be surprised or amazed to see news headlines that are persuasive, judgmental, provocative, even more interesting than the content of news delivered.

The languages in the mass media are used by various circles for various purposes. In general, media readers have an interest in mass media to obtain new information. The authors of textbooks utilize the mass media in addition to the interest of information (knowledge source) as well as an example of presentation of discourse or exercise materials. Writers of Indonesian textbooks take a lot of discourse from the mass media (newspapers, tabloids, magazines, internet) as examples of text, exercise materials, or sources of knowledge.

Based on Anshori's (2002) research on the source of text (discourse) of high school Indonesian textbooks shows that as many as $41.67 \%$ of class X source discourse comes from newspapers and magazines. The source of the discourse of class XI textbooks as much as $79.12 \%$ comes from newspapers and magazines. Sources of discourse textbooks of class XII as much as $52.94 \%$ comes from newspapers and magazines. This data shows the high frequency of newspaper usage as a learning resource in schools in Indonesia. The high use of discourse sourced from newspapers and magazines means the dynamics of news coverage in the mass media, indirectly become part of language learning in the classroom.

Based on the various studies that have been conducted by experts on textbooks, research using framing analysis in understanding the discourse in the textbook is still somewhat rare. On the other hand, the use of journalism discourse in Indonesian language learning at schools requires the teachers' ability to understand more in depth about journalism activities and journalism language analysis, so that teachers have sufficient ability to understand and put the journalism language in language learning at schools.

Similarly, research on discourse by using discourse analysis has been conducted by many previous experts, but research on journalism discourse in textbook with framing analysis is still somewhat rare. Various perspectives are given in understanding discourse, both as text and as the source of the message. Heracleous (2006) examines discourse in the context of enterprise organizational change. Using the ethnographic paradigm, a search of the company's players is done by looking at how the company's managers strive to manage the organization effectively. Data were collected through instruments ranging from lower to higher levels, in addition to interviews with senior managers. This research is conducted by analyzing dominant discourse, strategic change discourse, and counter-discourse.

Ethnographic research was also conducted by Georgakapoulou (1998) who examined conversations of three Egyptian women who have been good friends for 17 years. The aspects analyzed are themes, plot, character of speech, and mode of delivery. The results showed that each participant made a different contribution in the figuration of different identity construction in the spoken discourse formed by the three persons.

Similar research has been conducted by Mulyana (2001) towards 25 Indonesians living in Melbourne, Australia. Mulyana found out the type of ethnic identity, namely religious ethnic, moderate ethnic, cosmopolitan ethnic, and nationalist ethnic. These four components show differences in self-image and selflocation of respondents in their social world, all of which are based on their initial socialization, maintained in their interactions with old significant others and their generalized others in new and modified states through interaction with new significant others. The study even though scientifically entered the area of sociology-anthropology, 
but the data respondents were delivered through discourse (interview). In other words, this identity is reflected in the spoken discourse of the respondents.

Meanwhile, research on mass media languages is also widely studied by Indonesian researchers and foreign researchers. Suroso (1999) analyzed the use of Indonesian language in Kompas, Media Indonesia, Republika, and Suara Pembaruan during the period of May-July 1999. Suroso (1999) showed that mass media do deviations in the form of morphological errors, syntax errors, vocabulary errors, and spelling errors. In the news according to Suroso (1999) there are differences in perspective reflected in the attitude of journalists based on certain ideological values, and it is reflected in the use of language in various aspects, namely the strategy of information presenting. Viewed from the perspective of newspapers there are four news perspectives as a manifestation of the value, knowledge, and point of view adopted. The four perspectives are (1) the prosociety perspective, (2) the pro-government perspective, (3) the neutral perspective, and (4) the religious perspective.

Hong (Ni, 2003) describes his research on four types of texts, namely academic writing, news texts, fiction, novels, and conversations. The study is of English background as a language corpus and is implemented in Singapore. The results of his research indicate that the phrase occurrence of objects in the type of text above is differentfrequency objects per 1000 words examined. The information presented on the object phrase in academic text is more compact than the text of the conversation. Noun phrase (NPs) that are not primary pronouns appear in academic text as much as 283.8 words, 248.5 word in news texts, 203.9 words in novel text, and in conversations as much as 118.6 words. Meanwhile, the percentage of occurrences of major pronouns of NPs in academic writing is $10.9 \%$, news as $17.6 \%$, novels as $38.6 \%$ and conversations as $57.7 \%$.

Based on previous studies it is clear that many perspectives and focuses are given to the topic of discourse, mass media and textbooks, both qualitatively and quantitatively. This shows that the language in mass media and textbooks is interesting to be studied and researched in various focus. In general, discourse studies are detached from the world of education, especially discourse in the mass media. This research is considered to have its own position because the discourse used as the study material is a discourse in the textbook, which is expected to contribute to the writing of textbooks and language learning at schools. In addition, the use of framing techniques is also a novelty in discourse analysis in school textbooks.

Based on data analysis of curriculum of education unit level (KTSP) in class X of Senior High School, there are four standards of competence $(50 \%)$ from eight competence standards and five basic competences (50\%) from 10 basic competences of language skills containing journalism elements. In grade XI of Senior High School there are four competence standards $(50 \%)$ of eight competence standards and five basic competences $(50 \%)$ of the 10 competence standards of language skills containing journalism elements. In grade XII of Senior High School there are two standards of competence $(25 \%)$ of eight competence standards and two basic competences $(22 \%)$ of the nine basic competences containing journalism elements. The elements of journalism in question are language activities that include materials derived from journalism practices (print and electronic mass media), and language activities that intersect directly with the activities (practice) of journalism, such as interviewing and writing news.

Many aspects of journalism in the curriculum prosecute teachers to have the competence of journalism and strategy in understanding journalism discourse as a product of mass communication. Indonesian teachers are not only able to understand how a story is compiled by including what, who, when, where, how, and why elements but also understand how a news loaded with frames of journalists is understood by the reader. Without such abilities, it is difficult for teachers to be able to teach adequate 


\section{Dadang S. Anshori}

Framing of journalism discourse to improve discourse competence of senior high school students

journalism discourse to students and form students into critical mass media users.

The discourse of journalism can not only be placed as a speech analyzed syntagmatically or paradigmatically, but it must also be understood the social cognition of the speaker. Understanding the social cognition of speakers is very important in journalism discourse because the news in the mass media involves various interests, whether journalists, media managers, community, and media owners. During this type of analysis is more widely used in the fields of science outside the language, but in accordance with its development the study becomes an important part of functional language studies.

The above thought confirms the importance of studying the framing construction of journalism discourse in textbooks and formulating analytical techniques in learning journalism discourse in accordance with the needs of learning which in turn is expected to increase the competence of the discourse of the students so that learning Indonesian language becomes more meaningful. In this context, the texts presented in Indonesian textbooks sourced from the mass media can not only be understood and taught as part of the realization of communicative purpose of language learning, but also can be used as an ingredient to improve the competence of discourse and critical thinking of the students in the language . Critical thinking is important for students so that they can utilize and empower all information obtained from the mass media for the benefit of their lives.

\section{METHOD}

This research used qualitative method. This research began with preliminary study in the form of observation of the discourse learning at school, study of Indonesian textbook, and study of literature about discourse, journalism discourse, framing analysis, and language learning. Based on the preliminary study, there had formulated topics and research problems. The developed theories are the discourses framing theory of Pan and Kosicki (Eryanto, 2007). The model development is done by complementing the structure of the analysis developed at the beginning. The developed structure consists of categories, syntax, script, thematic, diction/phrase, and rhetorical.

Qualitative methods developed are interpretive (Mulyana, 2001; Muhadjir, 2000), that researchers engaged in interpreting data that is deemed not fixed, but interpretive. This interpretive study was first developed by Geertz in the scientific field of Sociology. Qualitative research methods are interpreted as research that produces qualitative data in the form of written or spoken words of the people or behaviors observed (Moleong, 2002). Qualitative research is considered to describe the object of research more complete and comprehensive (Fraenkel and Wallen, 1993). Data or corpus of research are in the form of journalism discourse in 10 textbooks of Indonesian High School taken purposively.

\section{RESULTS AND DISCUSSION The use of journalism discourse in textbooks}

Based on data analysis of journalism discourse use in 10 high school Indonesian textbooks were found very diverse discourses in terms of number, topic, source, type and usage. This diversity is possible given the ability of each writer to understand the different curriculum.

The diversity of this discourse also occurs because there is no provision guided by textbook authors regarding the use of discourse in textbooks. Each author performs his own creations in utilizing the source of mass media. Technically, the reason for the use of discourse from newspapers, magazines, the internet is seen by authors as easier to obtain than other sources. The choice of theme or topic, type of discourse, competence standard and basic competence classification leads to different author's orientation. Based on the classification of language and literary competence, for example, authors who emphasize literary competence will write textbooks by giving greater weight to the field of literature than to the field of language; and vice versa. Thus, in the framework of material balancing, especially discourse, the absence of these guidelines has led to the diverse directions of each author of the book. 
The vast amount of discourse in Indonesian textbooks indicates that textbook authors make the discourse a body or an important part of textbook writing. This is evidenced by the average frequency of the discourse of 10 books amounted to 61.6 pieces of discourse. This large number indicates that discourse is an important learning resource for language learning. Moreover, low selection of discourse themes will have implications for the diversity of information presented, even all themes or topics will be presented in textbooks. As a result, the students must have the ability to understand new vocabulary in the context of its use, old vocabulary, new sentences, and new discourses.

The diversity of discourse from the aspect of the number, topic, source, type and usage will have implications on the readiness of students in dealing with these various discourses. Although these discourses can be paralleled for other learning, the ability of students to understand the content of the discourse is often a constraint. In reading competence, the ability to understand the content of discourse is directly related to the students' ability to read effectively. Especially when associated with the position of discourse as a basis of improvement of one's life, as mentioned Vygotsky (1986) that is the involvement of high-level mental, psychological and intellectual function in understanding the discourse for the sake of progress and improvement of life. In this context, of course, all forms of diversity must be considered so that the interests of language learning are truly achieved.

Meanwhile, the average frequency of journalism discourse is 19.7 pieces of discourse. If the average amount of journalism discourse is $32.58 \%$. This figure is of course quite large considering that in addition to newspapers, magazines, and the internet, actually the author of the book has the possibility to take the discourse from other sources. There is a tendency of the author of the book to take the discourse by considering the aspects of convenience and practicality. Newspapers, magazines, tabloids, and the internet today can be obtained much easier and cheaper than books. Moreover, the media has the advantages of diversity of aspects of the contents. Viewed from the topic of discourse aspect, journalism discourse is generally adapted to the subject matter or chapter in the book. Before determining the topic of discourse the authors of the book determine the chapter theme beforehand. The next stage, the authors seek and determine the discourse in accordance with the theme of the chapter. This book-making pattern is highly possible given the determination of lesson topics or chapters is not specified in the curriculum.

Based on the position and function of the discourse (text) in relation to language competence, journalism discourse is placed at the beginning of the explanation of matter, in the middle as an example or case, and at the end as an affirmation of the material or proof. In the listening competence of the discourse is generally used as sources and examples; on reading comprehension discourse used as a source of reading; on speaking competence discourse is used as an example; on the competence of writing discourse is used as an example and source of practice. In general, journalism discourse has a function as an example of competence, reading resources, and sources of analysis in the exercise. Hymes (1972) calls the ability to communicate means to create discourse, as communicative competence.

Based on the classification of literacy capabilities developed by Wells in general the students are at the level of the ability of performative discourse or "breaking the code", that is the ability to speak or control communication between people who are known or know the relationship between spoken and written language symbols. Some students have put discourse on the informational level, understanding the text in the sense of connecting what is in the text with the background of knowledge so that there will be construction of meaning that can respond to the meaning. However, in discourse learning the students have not reached the level of epistemic discourse, that is capable of using language for the development of science. Whereas this level of ability is expected to be 


\section{Dadang S. Anshori}

Framing of journalism discourse to improve discourse competence of senior high school students

owned by the students in mastering the discourse. With epistemic abilities, students can make discourse as a medium to improve science skills and will in turn build awareness and understanding of the importance of information for their lives.

The large portion or frequency of journalism discourse in Senior High School Indonesian textbooks gives an indication that the authors place the actuality or novelty of information as part of the textbook writing strategy. This actuality will have implications for the presence of new information that can be transferred to the students. Thus, through the presence of journalism discourse in textbooks, students constantly update the information they obtain. The same thing is done by readers of print media: updating information or knowing the latest information. However, the pursuit of actuality does not mean that the authors of the book can easily determine the type of journalism discourse because not all journalism discourse can be well received. The authors of the book should consider many aspects before choosing the discourse, the theme, content, type, length of writing, and the degree of legibility.

The most important thing in considering the presence of journalism discourse is the position of journalism discourse with the terms of interest. The journalism discourse in fact not only conveys some information to the reader, but also transmits certain interests and agendas, either explicitly or implicitly. Brown and Yule (1996) assert that discourse analysts are obligated to investigate what language is being used. Fairclough (1992) also believes that discourse domination is an increasingly dominant way of showing one's dominance or power over another. This opinion is relevant to the fact of this research that journalism discourses contained in textbooks have power and dominance. Therefore, Heracleous (2006) argues that discourse approach as a communication activity is one way of interpreting social construction and existing reality.

Social construction and reality in journalism discourse can be observed through analysis of the news frames. The results showed that the frames (frames) of journalism discourse in Senior High School Indonesian textbooks is packed in various viewpoints in accordance with the news topic and facts. Based on the results of the analysis, it turns news frames play an important role in determining the direction of news, both aspects of writing and selection of materials and news data presented. Projection of facts and omission of facts are done by journalists in accordance with the news frame. The projection and disappearance is the way journalists construct the news. In other words, news is constructed by frame. It is this framework that gives perspective (tendency to part) of a news, which based on Suroso's (1999) research consists of (1) pro-society perspective, (2) pro-government perspective, (3) neutral perspective, and (4) religious perspective.

\section{Journalism discourse in textbooks based on news values}

In the aspect of news values, this research shows that the journalism discourse in Indonesian textbooks can be explained below. Of the 30 news that became the data of this study, as many as 16 news $(53.33 \%)$ has an important news value and prominance. The importance and magnitude of the commodity can be measured from the position of loading the news in the media and the position of the news in the conversation in the community. Those news are news about the destruction of forests, the outer islands of Indonesia, violations of the implementation of the National Exam and others. Viewed from the humanitarian aspect (human interest), from 30 data of this research found only 8 news data $(26,66 \%)$ containing human element or involving humanity aspect. The rest, which is 22 news data $(73.33 \%)$ pertained to news that does not have the element of humanity. Based on the aspect of conflicts (conflix), from 30 data of this study found as many as 15 news $(50 \%)$ meet the aspects of conflict. In this case the aspect of disagreement is categorized into two parts, namely the first is contradiction of the two facts presented in the news and the contradictions in the news headlines. Based on extraordinary or unusual aspects, from 30 
research data found 11 news data $(36.66 \%)$ news have unusual or extraordinary elements. The remaining 19 news data $(63.33 \%)$ did not meet the extraordinary or unusual elements. Based on the proximity aspect, most of the news fulfilled the proximity aspect, from 30 research data, 19 news $(63.33 \%)$ fulfilled the aspect of closeness while the remaining 11 news $(36.66 \%)$ did not fulfill the closeness element. When viewed from each title and news content, there are only two news that meet all aspects of the news values above, the news about the expedition of the forefront of the archipelago Islands and Timika riots. In addition to these two news not all aspects of news value is met in the news that became the data of this study.

Data on the aspect of the news values indicate that the discourse in the textbook does not have all the elements of news value: prominance, human interest, conflix, unusual, and proximity. Selection of journalism discourse conducted by the author thus is not based on the five principles of the news, but done randomly. From the aspect of news value, of course, many journalism discourses are not eligible to be presented in the textbook to be the source (reference), except in its position as an example. Similarly the author of the book should choose the type of news that is worthy to be presented in the textbook, given the light news (soft news) will be different from the feature-type news. Research data indicate that it is unlikely that the author of the book will notice such things.

\section{Construction of journalism discourse framing in textbooks}

Based on the framework developed by Pan and Kosicki, namely syntax, script, thematic, and rhetorical it is known that from 30 journalism discourse of this research data, all meet the frame device. The way journalists compose news (syntax) is done using headlines, leads, background information, quotes, sources, statements, and closings.

Almost all journalism discourse has headlines, leads and background information. However, some journalism discourses do not have news sources, statements, and citations, especially on feature-type news or reports (trevel features). Based on how to tell the news (scripts), $5 \mathrm{~W}+\mathrm{H}$ elements are used in many journalism discourses, but not all of these elements of fulfillment are fulfilled, especially the why and how elements. The results of this study reinforces previous research (Suroso, 1999) that the language of journalism is poor structure, because in most news does not contain elements of why and how. When viewed from language learning, the type of news that does not contain the elements of why and how pertained discourse that is not critical and can not make students critical. Critical ability becomes one of the domains of psychomotor goals taxonomy in language learning. Stern (1992) develops a taxonomy of psychomotor or behavioural goals that include mechanical skill domains, knowledge skills, transfer skills, communication skills and criticism skills.

Based on how to write the news (thematic), journalism discourses have between 2 to 6 themes. The journalism discourse studied also has details with many variations, intra-sentence and inter-sentence coherence, various sentence forms, and pronouns of people (aposition) as the source position of the news source. The choice of sentence, detail, coherence, and sentence form is one way for journalists in writing news. Meanwhile, based on how to emphasize the news (rhetoric), the discourses in this study use lexicon and metaphor as a way of emphasizing the news. Keywords (lexicon) are used in the title or body of the news. Metaphors are widely used to describe cases, facts and events to make the news more engaging and reader-friendly. Meanwhile, the elements of graphics and presuppositions are not often found in this discourse.

The emphasis of diction, figure of speech, stigmatization, acronymization, and technical rationing characterize the language of journalism. The studies of Heryanto (2000), Lewuk (1995), Alwasilah (20003), Halliday (1985), Rachmat (1984) indicate that journalism language is used through a specific strategy for the interest of journalists or media owners to the reader. Based on these studies, 


\section{Dadang S. Anshori}

Framing of journalism discourse to improve discourse competence of senior high school students

the language of journalism appears to be a tool for stigmatizing a case and the occurrence of politicization in the case. In this study, the strategy appears on the rhetorical device, the way journalists emphasize the news. The choice of diction and the way of presentation (figure of speech) becomes the power of journalists to emphasize the news frame..

\section{Analysis model of journalism discourse in language learning}

The analysis model of journalism discourse developed focuses on the structure of analysis, ie categories, scripts, syntax, thematic, diction/phrase, and rhetorical. This model of analysis will enable readers of journalism discourse to be open minded, critical, and understand the nature of the presence of journalism discourse in language learning. The design of this research development covers the theoretical basis, the characteristics and principles of learning, the role of the teacher, the role of the students, the themes and topics, the focus of learning, the learning objectives, methods and techniques, materials and resources, learning scenarios, evaluation and follow-up. The theoretical basis used is critical linguistic theory, the theory of constructive discourse, and the theory of frames. Characteristics and principles of learning include critical, discursive, analytical, ideological, and functional. Meanwhile the role of the teacher becomes the facilitator of the learner and the role of the student as a critical discourse analyst in identifying the facts of the language. The themes and topics of learning are tailored to Competence Standard and Basic Competence. Similarly, the focus of learning and learning objectives. Learning methods and techniques should be inquiry (tracing) and analytical. The learning scenario consists of exploration, elaboration, and confirmation. This development uses an authentic evaluation of students' work results (student portfolios) as a valued product in addition to the assessment of the learning process.

\section{CONCLUSION}

The use frequency of journalism discourse in Indonesian textbooks are high and very diverse in types and themes. The use of journalism discourse in the 10 textbooks of research data is very diverse in terms of number, topic, source, and usage. This diversity occurs because there is no provision guided by textbook authors regarding the use of discourse in textbooks. Based on the position and function of discourse (text) in relation to language competence, journalism discourse is at the beginning of explanation of matter, in the middle as an example or case, and at the end as the material or proof. In general, journalism discourse has a function as an example of competence, reading resources, and sources of analysis in the exercise.

The journalism discourse in Indonesian textbooks has different news values. In general, journalism discourse meets the values of the news, namely the important elements and great scope, the element of humanity (human interest), elements of conflict (conflix), unusual or extraordinary elements, and proximity. When viewed from each title and news content, there are only two news that meet all aspects of the news values above, the news about the expedition of the forefront of the archipelago Islands and Timika riots. In addition to these two news not all aspects of news value is met in the news that became the data of this study.

Frame construction (framing) of journalism discourse in Senior High School Indonesian textbooks is packed in various viewpoints according to news topics and facts. Based on research data, it turns news frames play an important role in determining the direction of news, both aspects of writing and selection of materials and news data presented. In other words, news is constructed by frame. Based on the analysis of the construction of journalism discourse frames is found the following important matters.

The analysis model of journalism discourse developed focuses on the structure of analysis, ie categories, scripts, syntax, thematic, diction/phrase, and rhetorical. This model of analysis will enable readers of journalism discourse to be open minded, critical, and understand the nature of the presence of journalism discourse in language learning. The development model undertaken 
in this study includes rational, theoretical basis, learning characteristics and principles, analytical structures, teacher and student positions, instructional materials, learning methods and techniques, learning scenarios, focus and learning objectives, and learning evaluations.

\section{REFERENCE}

Alwasilah, A. C. (2003). Bangsa yang besar adalah bangsa yang menulis. Pidato Pengukuhan Jabatan Guru Besar Tetap dalam Bidang Pendidikan Bahasa dan Sastra Inggris, FPBS UPI, 17 Oktober 2003. Bandung: UPI.

Anshori, D. S. (2002). Bahasa koran sebagai bahan ajar pembelajaran bahasa. Bahasa \& Sastra, 2(3), 8294.

Brown, G., \& Yule, G. (1996). Analisis wacana. Jakarta: Gramedia.

Eriyanto. (2007). Framming, konstruksi, ideologi, dan politik media. Yogyakarta:: LKiS

Fairclough, N. (1992). Language and power. London: Longman.

Fraenkel, J. R., \& Wallen, N. E. (1993). How to design and evaluate research in education. New York: McGraw-Hill, Inc.

Georgakapoulou, A. (1998). Small and large identities in narative (inter)action. In De Fina, A., Schiffrin, D., \& Bamberg, M. (eds.), Discourse and identity. Cambridge: Cambridge University Press.

Halliday, M. A. K., \& Hasan, R. (1985). Language context and text: Aspects of language in a social, semiotic perspective. Victoria: Deakin University Press.
Heracleous, L. (2006). Discourse, interpretation, organization. Cambridge: Cambridge University Press.

Heryanto, A. (2000). Perlawanan dalam kepatuhan, esai-esai budaya. Bandung: Mizan.

Hymes, D. (1972). On communicative competence. In J. B. Pride, \& J. Holmes (eds.), Sociolinguictics. Harmondsworth: Penguin.

Latief, Y., \& Ibrahim, I.S. (1996). Bahasa dan kekuasaan. Bandung: Mizan.

Lewuk, P. (1995). Kritik filosofis atas pembangunan: Beberapa serpihan pemikiran. Jakarta: Fosko'66.

Muhadjir. N. (2000). Metodologi penelitian kualitatif (4th edition). Yogyakarta:: Rake Sarasin.

Mulyana, D. (2001). Metodologi penelitian kualitatif, paradigma baru ilmu komunikasi dan ilmu sosial lainnya. Bandung: Rosdakarya.

Moleong, L. J. (2002). Metodologi penelitian kualitatif. Bandung: Remadja Rosdakarya.

Ni, Y. (2003). Noun phrases in media texts: A qualitative approach. In Aitchison, J., \& Lewis, D.M. (eds.), New media language. London: Routledge.

Vygotsky, L. S. (1986). Thought and language. Cambridge: The MIT Press.

Rakhmat, J. (1984). A model for the study of mass media effects on political leaders: A study in Indonesia. Unpublished thesis. USA: Iowa State University.

Stern. H. H. (1992). Issues and options in language teaching. Oxford: Oxford University Press.

Suroso. (1999). Bahasa jurnalistik perspektif berita utama politik surat kabar Indonesia pada awal era reformasi. Unpubished dissertation. Jakarta: PPS UNJ. 
Dadang S. Anshori

Framing of journalism discourse to improve discourse competence of senior high school students 